AGRICULTURE AND BIOLOGY JOURNAL OF NORTH AMERICA

ISSN Print: 2151-7517, ISSN Online: 2151-7525, doi:10.5251/abjna.2011.2.4.673.679

(C) 2011, ScienceHu $\beta$, http://www.scihub.org/ABJNA

\title{
Effect of microwave heating of linseed oil on the formation of primary and secondary oxidation products
}

\author{
Mohamed G. Megahed
}

Fats and Oils Department, National Research Centre, Dokki, Cairo. Egypt.

E-mail: dr_mgmegahed@hotmail.com

\begin{abstract}
The purpose of the present study was to explore the influence of microwave heating for different periods on the primary and secondary oxidation, total oxidation as well as conjugation of stripped and non-stripped linseed oils. Color index of the oil samples was also evaluated to show changes of color during periodical heating. It was generally found that a significant increase in peroxide value, $p$-anisidine, total oxidation, conjugated diene and conjugated triene for microwave heating periods of 1,2,3,4 and 5 min. Two samples (stripped and non-stripped) of linseed oil (microwave treated) were analyzed individually in triplicate, and the results were reported as mean $\pm S D$. Statistical significance of the differences between mean values was assessed by one-way ANOVA. It was found that stripped linseed oil (absence of antioxidants) is prone to heat effect than the non-stripped oil (with antioxidants). Generally, it is recommended that polyunsaturated oils have to be prevented from heat treatment for cooking purposes (e.g. soybean and linseed oils), since they contain linoleic and linolenic acids which are sensitive to oxidation.
\end{abstract}

Keywords: Linseed oil, microwave heating, primary oxidation, secondary oxidation, total oxidation.

\section{INTRODUCTION}

Microwave ovens are present in the majority of homes and today more people use microwave ovens for cooking and reheating (1-3).

Microwave process can offer several distinct advantages when compared to conventional methods. These advantages include speed of operation, energy savings, precise process control, faster start up and shut-down times $(4,5)$. Heating of food in a microwave oven is caused by interaction of an electromagnetic field with the chemical constituents of food. These interaction comprising molecular friction and excitation generate heat necessary for cooking purposes $(2,3,6)$.

The effect of microwave heating on animal and vegetable fats have been investigated $(1,4,7)$ as have its influences on thermo-oxidative stability of common oils and fats in house-hold use. Little has been published on the changes in composition and oxidative stability of the oils during microwave oven heating (8-10).

Although microwave heating can provide several advantages over conventional food processing method, but objectionable compounds are produced in microwave foods (11-13).
This work was devoted to study the effect of microwave heating on the primary and secondary oxidation as well as conjugation of periodical heating of stripped and non-stripped linseed oil. It is worthy to mention that linseed oil was selected for this study owing to its sensitivity to oxidation than any other oils. Meanwhile, it was feasible to predict the formation of the harmful compounds arising from heating effect of microwave heating.

\section{MATERIALS AND METHODS}

Materials: Representative samples of developed linseed were collected from 2009 production in Tanta, Egypt. The other used chemicals were of high purity and technical grade (Merk, Germany and BDH, England).

\section{METHODS}

Oil extraction: Soxhlet apparatus technique was utilized for oil extraction from dried and ground seeds using redistilled $n$-hexane according to the method of AOCS (14).

Fatty acid composition: Linseed oil methyl esters were prepared according to IUPAC (15). Determination of linseed fatty acids composition was performed as described by Mitruke (16) using a 
Hewlen Packard HP 6890 gas chromatograph, operated under the following conditions:

Detector, flame ionization (FID); column, capillary, $30.0 \mathrm{~m} \times 530 \mu \mathrm{m}, 1.0 \mu \mathrm{m}$ thickness, polyethylene glycol phase (INNO Wax); $\mathrm{N}_{2}$ with flow rate, $15 \mathrm{ml}$ per min with average velocity $89 \mathrm{~cm} / \mathrm{s}(8.2 \mathrm{psi}) ; \mathrm{H}_{2}$ flow rate, $30 \mathrm{ml}$ per min; air flow rate, $300 \mathrm{ml}$ per min; split ratio, $8: 1$, split flow, $120 \mathrm{ml}$ per min; gas saver, $20 \mathrm{ml}$ per min. Detector temperature, $280^{\circ} \mathrm{C}$; column temperature, $240{ }^{\circ} \mathrm{C}$; injection temperature, $280^{\circ} \mathrm{C}$. Temperature programming starting from $100{ }^{\circ} \mathrm{C}$ to reach a maximum of $240^{\circ} \mathrm{C}$ was used for eluting the fatty acid methyl esters. The identification of peaks was made as compared with chromatograms of saturated fatty acid methyl esters (Sigma, USA).

Chemical characteristics of oil : Chemical characteristics of the oil were conducted according to the method of AOCS (14).

Stripping of oil: The oil was freed from the tocopherols as well as any other antioxidant. This was done by running the oil miscella soluble in $\mathrm{n}$ hexane through silica gel (60-120 mesh) column. The stripped oil thereafter was checked by thin layer chromatography (TLC) to ensure that the oil is clear from antioxidants.

Microwave heating of stripped and non-stripped oil: A microwave oven (Samsung, M9245, Korea) capable of generating $1000 \mathrm{~W}$ power at $2450 \mathrm{MHz}$ was used. $20 \mathrm{~g}$ oil samples were placed into pyrex ptri dish $(10.0 \mathrm{~cm}$ diameter) with oil thickness of 4.0$5.0 \mathrm{~mm}$, then heated with microwave at $2450 \mathrm{MHz}$ for 1, 2, 3, 4 and 5 min, respectively.

Primary oxidation of oil: Primary oxidation was measured by peroxide value (PV) according to the method of AOCS (14).

Secondary oxidation of oil: Secondary products were measured by para-anisidine value $(p-A V)$ according to the method of AOCS (14).

Total oxidation of oil : The total oxidation was calculated as follows:

$$
\text { Total oxidation }=2 . \mathrm{PV}+p-\mathrm{AV}
$$

Conjungated dienes and trienes: $A$ sample of about $200 \mathrm{mg}$ was dissolved in $100 \mathrm{ml}$-hexane and mixed thoroughly. The absorption was measured in the UV region using a Shimadzu UV-Visible 240 Recording Spectrophotometer (Tokyo, Japan) and the optical densities were measured at 233 and 268 $\mathrm{nm}$ for dienes and trienes, respectively. The percentages of conjugated acids were calculated according to the method of A.O.C.S. (14).

Color index $(\mathrm{Cl})$ : Oil samples were diluted with carbon tetrachloride at ratio of $1: 1$ by volume for light colored samples and $1: 9$ by volume for dark colored samples. The solution was measured in the UV region using Shimadzu Recording Spectrophotometer (Tokyo, Japan) at wave lengths ranging from 320 to $700 \mathrm{~nm}$. A total of 16 readings of an optical density (O.D) were taken with $10 \mathrm{~nm}$ difference within $400-550 \mathrm{~nm}$ range. The sum of 16 O.D. readings are multiplied by 10 to give an approximation for the area under absorption curve, which indicated the concentration of the coloring matter in the oil, i.e. color index (17).

Statistical analysis: Two samples (stripped and non-stripped) of linseed oil (microwave treated) were analyzed individually in triplicate, and the results were reported as mean $\pm S D$. Statistical significance of the differences between mean values was assessed by one-way ANOVA with SAS software (18). Tukey multiple comparison procedure was used to compare the means. A probability to $p \leq 0.05$ was used to establish the statistical significance.

\section{RESULTS AND DISCUSSION}

Fatty acids composition of linseed oil is recorded in Table (1).

Table: 1. Fatty acids composition of linseed oil.

\begin{tabular}{|c|c|c|c|c|c|c|}
\hline \multirow{2}{*}{$\begin{array}{c}\text { Extracted } \\
\text { oil }\end{array}$} & \multicolumn{4}{|c|}{ Fatty acids (\%) } \\
\cline { 2 - 7 } & \multicolumn{3}{|c|}{$\begin{array}{c}\text { Saturated fatty } \\
\text { acids }\end{array}$} & \multicolumn{3}{c|}{$\begin{array}{c}\text { Unsaturated fatty } \\
\text { acids }\end{array}$} \\
\cline { 2 - 7 } & $\mathrm{C}_{14: 0}$ & $\mathrm{C}_{16: 0}$ & $\mathrm{C}_{18: 0}$ & $\mathrm{C}_{18: 1}$ & $\mathrm{C}_{18: 2}$ & $\mathrm{C}_{18: 3}$ \\
\hline $\begin{array}{c}\text { Linseed } \\
\text { oil }\end{array}$ & 1.77 & 8.76 & 6.55 & 18.16 & 20.64 & 44.12 \\
\hline
\end{tabular}

$\mathrm{C}_{14: 0}$, Myristic; $\mathrm{C}_{16: 0}$, Palmitic; $\mathrm{C}_{18: 0}$, Stearic; $\mathrm{C}_{18: 1}$, Oleic; $\mathrm{C}_{18: 2}$, Linoleic; $\mathrm{C}_{18: 3}$, Linolenic.

It can be seen from Table (1) that the fatty acids contents of linseed oil were $17.08 \%$ of saturated fatty acids and $82.92 \%$ of unsaturated fatty acids, where the saturated : unsaturated ratio were $(1: 4.85)$, respectively.

Linolenic acid constitutes more than $53.0 \%$ of the unsaturated fatty acids of linseed oil, while palmitic acid makes more than $51.0 \%$ of the saturated fatty acid of linseed oil. These results are in a good agreement with the previous results reported by Young (19). 
Chemical characteristics of stripped and non-stripped linseed oil subjected to microwave heating were

studied and are presented in Table (2).

Table 2. Chemical characteristics of stripped and non-stripped linseed oil subjected to microwave heating.

\begin{tabular}{|c|c|c|c|c|c|c|}
\hline \multirow{2}{*}{$\begin{array}{c}\text { Heating } \\
\text { time }(\mathrm{min})\end{array}$} & \multicolumn{2}{|c|}{ Acid value $(\mathrm{mg} / \mathrm{g})$} & Peroxide value $(\mathrm{mEq} / \mathrm{kg})$ & \multicolumn{2}{c|}{ lodine value (g/100g) } \\
\cline { 2 - 6 } & Stripped oil & Non-stripped oil & Stripped oil & Non-stripped oil & Stripped oil & Non-stripped oil \\
\hline 0 & $1.14 \pm 0.01^{\mathrm{C}, \mathrm{a}}$ & $0.57 \pm 0.01^{\mathrm{C}, \mathrm{b}}$ & $5.13 \pm 0.06^{\mathrm{F}, \mathrm{a}}$ & $4.56 \pm 0.06^{\mathrm{F}, \mathrm{b}}$ & $160.53 \pm 2.01^{\mathrm{D}, \mathrm{b}}$ & $184.0 \pm 2.30^{\mathrm{B}, \mathrm{a}}$ \\
\hline 1 & $1.14 \pm 0.02^{\mathrm{C}, \mathrm{a}}$ & $0.57 \pm 0.01^{\mathrm{C}, \mathrm{b}}$ & $10.26 \pm 0.14^{\mathrm{E}, \mathrm{a}}$ & $6.27 \pm 0.08^{\mathrm{E}, \mathrm{b}}$ & $266.49 \pm 3.60^{\mathrm{A}, \mathrm{a}}$ & $194.16 \pm 2.62^{\mathrm{A}, \mathrm{b}}$ \\
\hline 2 & $1.72 \pm 0.02^{\mathrm{B}, \mathrm{a}}$ & $1.14 \pm 0.01^{\mathrm{B}, \mathrm{b}}$ & $16.53 \pm 0.21^{\mathrm{D}, \mathrm{a}}$ & $7.41 \pm 0.09^{\mathrm{D}, \mathrm{b}}$ & $249.36 \pm 3.12^{\mathrm{B}, \mathrm{a}}$ & $194.16 \pm 2.43^{\mathrm{A}, \mathrm{b}}$ \\
\hline 3 & $1.72 \pm 0.02^{\mathrm{B}, \mathrm{a}}$ & $1.14 \pm 0.02^{\mathrm{B}, \mathrm{b}}$ & $18.24 \pm 0.25^{\mathrm{C}, \mathrm{a}}$ & $8.55 \pm 0.12^{\mathrm{C}, \mathrm{b}}$ & $209.38 \pm 2.83^{\mathrm{C}, \mathrm{a}}$ & $192.25 \pm 2.60^{\mathrm{A}, \mathrm{b}}$ \\
\hline 4 & $2.29 \pm 0.03^{\mathrm{A}, \mathrm{a}}$ & $1.72 \pm 0.02^{\mathrm{A}, \mathrm{b}}$ & $19.38 \pm 0.24^{\mathrm{B}, \mathrm{a}}$ & $17.10 \pm 0.21^{\mathrm{B}, \mathrm{b}}$ & $203.04 \pm 2.54^{\mathrm{C}, \mathrm{a}}$ & $190.98 \pm 2.39^{\mathrm{A}, \mathrm{b}}$ \\
\hline 5 & $2.29 \pm 0.03^{\mathrm{A}, \mathrm{a}}$ & $1.72 \pm 0.02^{\mathrm{A}, \mathrm{b}}$ & $21.09 \pm 0.28^{\mathrm{A}, \mathrm{a}}$ & $19.95 \pm 0.27^{\mathrm{A}, \mathrm{b}}$ & $117.38 \pm 1.58^{\mathrm{E}, \mathrm{b}}$ & $190.39 \pm 2.57^{\mathrm{BA}, \mathrm{a}}$ \\
\hline
\end{tabular}

Values are presented as mean \pm SD of duplicate samples analyzed in triplicate.

The same capital litter in the same column indicates there is no significant difference .

The same small litter in the same row indicates there is no significant difference for each parameter.

It is clearly seen from table (2) that the acid value of stripped and non-stripped linseed oil have been increased with increasing time from (1-5) min. On the other hand the acid value of stripped linseed oil was slightly higher than those of non-stripped sample. At 1 min heating the acid value of stripped oil sample was (1.14), while the non-stripped sample was (0.57). At the end of 5 min microwave heating the acid value of stripped and non-stripped oil were 2.29 and 1.72 , respectively. Moreover, gradual increase of peroxide value was noticed with microwave heating time. These results are in a good agreement with our previously results (4) and those reported by Farag et al. (20) and Yoshida et al. (21). It was found that peroxide values of stripped samples were higher than those of non-stripped samples due to the absence of natural antioxidants removed from the stripped oil (22). From the obtained results it could be also noticed that the microwave heating had significant effect on iodine value and showed marked increase up to 2 minutes and sudden decrease during heating at 2 minutes heating and forward by marked decrease up 3,4 and 5 minutes heating. It was also noticed that the heating of non-stripped oil has a little effect on the oil. This fluctuation of iodine value in both samples (i.e. stripped and non-stripped oil) may be due to the possibility of formation unsaturated compound different in structure than the non-heated original oil $(1,4,22)$.

Color index of stripped and non-stripped linseed oil as measured spectrophotometricly at different wave length is illustrated in Table (3).

Table : 3. color index of stripped and non-stripped linseed oil subjected to microwave heating.

\begin{tabular}{|c|c|c|}
\hline \multirow{2}{*}{ Heating time $(\min )$} & Color index \\
\cline { 2 - 3 } & $140.38 \pm 1.75^{\mathrm{B}, \mathrm{b}}$ & $373.50 \pm 4.67^{\mathrm{AB}, \mathrm{a}}$ \\
\hline 0 & $149.10 \pm 2.01^{\mathrm{A}, \mathrm{b}}$ & $381.45 \pm 5.15^{\mathrm{A}, \mathrm{a}}$ \\
\hline 1 & $140.99 \pm 1.76^{\mathrm{B}, \mathrm{b}}$ & $365.24 \pm 4.57^{\mathrm{BC}, \mathrm{a}}$ \\
\hline 2 & $138.45 \pm 1.87^{\mathrm{B}, \mathrm{b}}$ & $363.84 \pm 4.91^{\mathrm{BC}, \mathrm{a}}$ \\
\hline 3 & $81.96 \pm 1.02^{\mathrm{C}, \mathrm{b}}$ & $357.86 \pm 4.47^{\mathrm{C}, \mathrm{a}}$ \\
\hline 4 & $27.75 \pm 0.37^{\mathrm{D}, \mathrm{b}}$ & $174.62 \pm 2.36^{\mathrm{D}, \mathrm{a}}$ \\
\hline 5 & & \\
\hline
\end{tabular}

Values are presented as mean \pm SD of duplicate samples analyzed in triplicate.

The same capital litter in the same column indicates there is no significant difference. The same small litter in the same row indicates there is no significant difference for each parameter. 
The color index of stripped oil decrease in value by time of heating till it reached a lower value (27.75) after 5 min heating. However non-stripped oil showed higher value (174.62) of color index after the same period of heating time. The higher values recorded for non-stripped oil may be due to interaction of tocopherols components with unsaturated fatty acid to give toco-red compound similar to that reported in soybean oil (23-25).

Influence of heating on stripped oil (free of antioxidants) and non-stripped oil (with antioxidants) is shown in Table (4) and Figures (1, 2).

Table : 4. The influence of microwave heating on $p$-anisidine value and total oxidation of stripped and non-stripped linseed oil.

\begin{tabular}{|c|c|c|c|c|}
\hline \multirow{2}{*}{ Heating time $(\min )$} & \multicolumn{2}{|c|}{$p$-anisidine value } & \multicolumn{2}{c|}{ Total oxidation } \\
\cline { 2 - 5 } & Stripped oil * & Non-stripped oil & Stripped oil * & Non-stripped oil \\
\hline 0 & $6.53 \pm 0.08^{\mathrm{E} . \mathrm{a}}$ & $2.63 \pm 0.03^{\mathrm{Fb}}$ & $16.79 \pm 0.21^{\mathrm{Fb}}$ & $11.75 \pm 0.15^{\mathrm{Fa}}$ \\
\hline 1 & $7.77 \pm 0.10^{\mathrm{E}, \mathrm{a}}$ & $4.60 \pm 0.06^{\mathrm{Eb}}$ & $28.29 \pm 0.38^{\mathrm{Eb}}$ & $17.14 \pm 0.23^{\mathrm{Ea}}$ \\
\hline 2 & $25.97 \pm 0.32^{\mathrm{D}, \mathrm{a}}$ & $6.13 \pm 0.08^{\mathrm{Db}}$ & $59.03 \pm 0.74^{\mathrm{Db}}$ & $20.95 \pm 0.26^{\mathrm{Da}}$ \\
\hline 3 & $44.95 \pm 0.61^{\mathrm{C}, \mathrm{a}}$ & $10.10 \pm 0.14^{\mathrm{Cb}}$ & $81.43 \pm 1.10^{\mathrm{Cb}}$ & $27.20 \pm 0.37^{\mathrm{Ca}}$ \\
\hline 4 & $49.28 \pm 0.62^{\mathrm{B}, \mathrm{a}}$ & $37.78 \pm 0.47^{\mathrm{Bb}}$ & $88.06 \pm 1.10^{\mathrm{Bb}}$ & $71.98 \pm 0.90^{\mathrm{Ba}}$ \\
\hline 5 & $63.72 \pm 0.86^{\mathrm{A}, \mathrm{a}}$ & $58.52 \pm 0.79^{\mathrm{Ab}}$ & $105.90 \pm 1.43^{\mathrm{Ab}}$ & $98.42 \pm 1.33^{\mathrm{Aa}}$ \\
\hline
\end{tabular}

* Stripped oil : antioxidant deficiency.

Values are presented as mean \pm SD of duplicate samples analyzed in triplicate.

The same capital litter in the same column indicates there is no significant difference .

The same small litter in the same row indicates there is no significant difference for each parameter.

Table : 5. Formation of conjugated dienes and trienes of stripped and non-stripped linseed oil subjected to microwave heating.

\begin{tabular}{|c|c|c|c|c|}
\hline \multirow{3}{*}{ Heating time (min) } & \multicolumn{4}{|c|}{ Conjugation } \\
\hline & \multicolumn{2}{|c|}{ Diene $234 \mathrm{~nm}$} & \multicolumn{2}{|c|}{ Triene $268 \mathrm{~nm}$} \\
\hline & Stripped oil & Non-stripped oil & Stripped oil & Non-stripped oil \\
\hline 0 & $5.32 \pm 0.07^{\mathrm{rb}}$ & $3.87 \pm 0.05^{\mathrm{Ea}}$ & $5.02 \pm 0.06^{\mathrm{rb}}$ & $2.62 \pm 0.03^{\mathrm{Fa}}$ \\
\hline 1 & $9.37 \pm 0.13^{\mathrm{Eb}}$ & $5.00 \pm 0.07^{\mathrm{Da}}$ & $5.70 \pm 0.08^{\mathrm{Eb}}$ & $2.92 \pm 0.04^{\mathrm{Ea}}$ \\
\hline 2 & $13.70 \pm 0.17^{\mathrm{Db}}$ & $5.31 \pm 0.07^{\mathrm{Ca}}$ & $6.82 \pm 0.09^{\mathrm{Db}}$ & $3.37 \pm 0.04^{\mathrm{Da}}$ \\
\hline 3 & $14.70 \pm 0.20^{\mathrm{Cb}}$ & $6.25 \pm 0.08^{\mathrm{Ba}}$ & $8.02 \pm 0.11^{\mathrm{Cb}}$ & $4.02 \pm 0.05^{\mathrm{Ca}}$ \\
\hline 4 & $17.52 \pm 0.22^{\mathrm{BD}}$ & $9.30 \pm 0.12^{\mathrm{Aa}}$ & $8.90 \pm 0.11^{\mathrm{BD}}$ & $5.00 \pm 0.06^{\mathrm{Ba}}$ \\
\hline 5 & $20.60 \pm 0.28^{A b}$ & $9.50 \pm 0.13^{\mathrm{Aa}}$ & $10.45 \pm 0.14^{\mathrm{AD}}$ & $7.08 \pm 0.10^{\mathrm{Aa}}$ \\
\hline
\end{tabular}

Values are presented as mean \pm SD of duplicate samples analyzed in triplicate.

The same capital litter in the same column indicates there is no significant difference .

The same small litter in the same row indicates there is no significant difference for each parameter.

Concerning the secondry oxidation ( $p$-anisidine value) of stripped oil, it can be seen that the $p$ anisidine values are higher than those of nonstripped oil samples. At 1 minute heating the $p$ anisidine reaches 7.77 in stripped oil corresponding to 4.60 in non-stripped oil. At 2 minutes heating the $p$ anisidine is 25.97 corresponding to 6.13 in none- stripped oil. At 3,4 and 5 minutes heating the $p$ anisidine of stripped oil increase to $44.95,49.28$ and 63.72 compared to $10.10,37.78$ and 58.52 in nonstripped oil, respectively $(1,22)$.

It is also seen from Table (4) that the total oxidation value of stripped oil is higher than that of nonstripped oil. You can see that after 1 min microwave 
heating the total oxidation reached 28.29 and 17.14 for stripped and non-stripped oil, respectively. While after $5 \mathrm{~min}$ the total oxidation values were 105.90 and 98.42 for the same samples respectively. These observation of high total oxidation values of stripped oil greater than non-stripped oil may be due to the presence of antioxidants with some colors preventing the oil from primary and secondary oxidation.

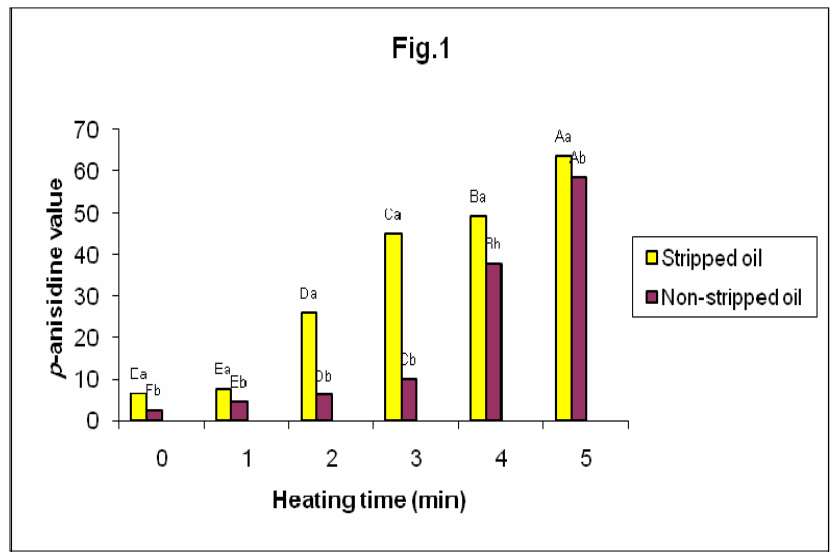

Fig : 1 The influence of microwave heating on $p$ anisidine value of stripped and non-stripped linseed oil.

Values are presented as mean \pm SD of duplicate samples analyzed in triplicate.

The same capital litter in the same column indicates there is no significant difference.

The same small litter in the same row indicates there is no significant difference for each parameter.

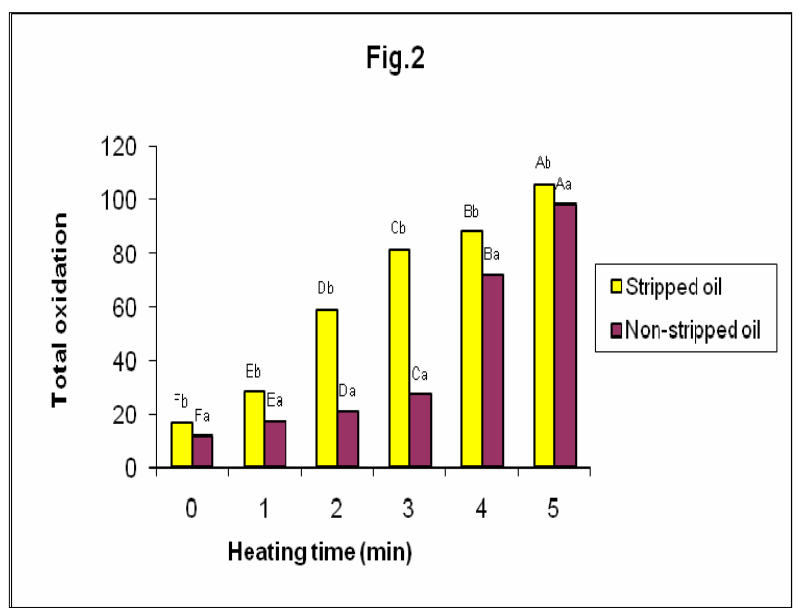

Fig 2. The influence of microwave heating on total oxidation of stripped and non-stripped linseed oil.
The formation of conjugated dienes and trienes of stripped and non-stripped linseed oil subjected to microwave heating are recorded in Table (5) and Figures $(3,4)$.

With reference to the effect of heating on the formation of conjugated dienes and trienes, it can be noticed that the conjugated diene in stripped oil samples are higher (9.37) than in case of nonstripped oil samples (5.00) after $1 \mathrm{~min}$ heating reaching 20.6 and 9.50 after $5 \mathrm{~min}$ heating, respectively. The same observation can be seen in conjugated triene of both stripped and non-stripped sample $(1,4,22,26)$.

This can be understood from role of antioxidants in the non-stripped oil which protect the oil from microwave heating which lead to formation of free radicals that attack the double bonds of poly unsaturated components of linseed oil.

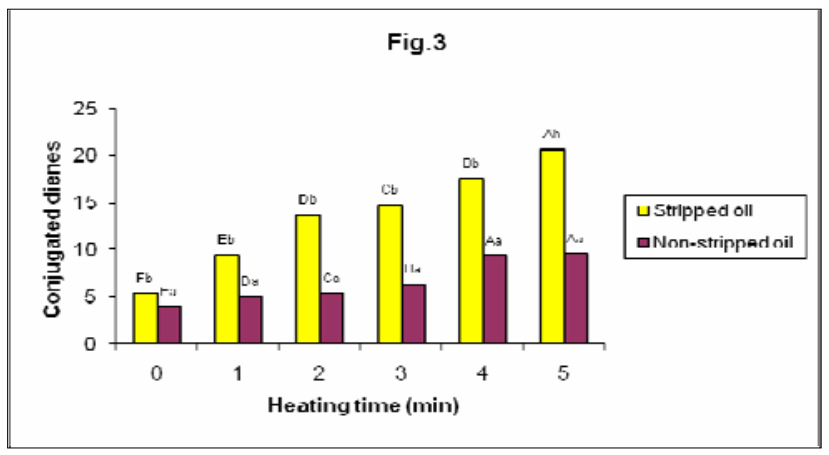

Fig 3. Formation of conjugated dienes of stripped and non-stripped linseed oil subjected to microwave heating.

Values are presented as mean $\pm S D$ of duplicate samples analyzed in triplicate.

The same capital litter in the same column indicates there is no significant difference .

The same small litter in the same row indicates there is no significant difference for each parameter. 


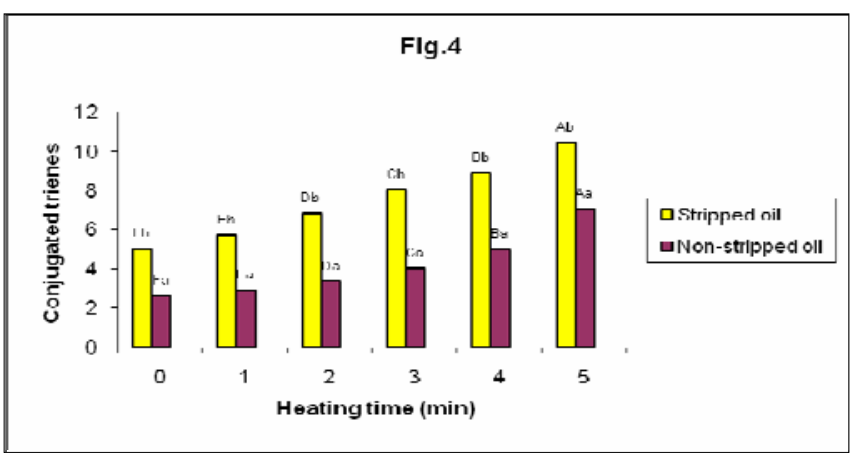

Fig : 4 Formation of conjugated trienes of stripped and non-stripped linseed oil subjected to microwave heating.

Values are presented as mean \pm SD of duplicate samples analyzed in triplicate.

The same capital litter in the same column indicates there is no significant difference .

The same small litter in the same row indicates there is no significant difference for each parameter.

\section{CONCLUSION}

1- Application of statistical analysis reveals that the samples were analyzed and the results include SD and statistical significant with the help of ANOVA.

2- The peroxide values of stripped samples were higher (10.26) than those of nonstripped samples (6.27) after one minute heating reaching 21.09 and 19.95 after five minutes heating, respectively.

3- The color index of stripped and non-stripped samples decrease generally in value by time of heating but the initial value of stripped oil sample is lower than the corresponding value of non-stripped oil samples.

4- Secondary oxidation as represented by paraanisidine value for stripped oil samples are generally higher than that of the non-stripped oil samples during the periodical heating process. Accordingly total oxidation is generally higher (28.29) in stripped oil sample than corresponding non-stripped oil sample (17.14) after one minute heating reaching 105.90 and 98.42 after five minutes heating, respectively.

5- It was advisable that polyunsaturated oils such as soybean and linseed oils are not recommended for cooking purposes by microwave as well as conventional heating process.

\section{ACKNOWLEDGEMENT}

Thanks are acknowledged to Prof.Dr.M.Hassan ElMallah for this criticism and valuable discussions.

\section{REFERENCES}

1. Anjum, F., F.Anwar, A.Jamil and M.lqbal (2006) Microwave roasting effects on the physico-chemical composition and oxdative stability of sunflower seed oil, J.Am Oil Chem.Soc. 83: 777-784.

2. Yoshida, H., Y. Hirakawa, and S.Abe (2002) Influence of microwave roasting on positional distribution of fatty acids of triacylglycerols and phospholipids in sunflower seeds (Helianthus annuus L.) Eur., J. Lipid Sci. Technol. 103: 201-207.

3. Yoshida, H., S. Abe, Y. Hirakawa, and S. Takagi (2001) Roasting effects on fatty acids distribution of triacylglycerols and phospholipids in sesame (sesamum indcum) seeds, J. Sci. Food Agric. 81: 620-626.

4. Megahed, M.G. (2001) Microwave roasting of peanuts: Effects on oil characteristics and composition Nahrung 45: 225-257.

5. Decareau, R. V. (1985) Microwave in the Food Processing Industry, Academic Press, Ine., New York.

6. Yoshida, H., Y. Hirakawa, and S.Abe (2001) Roasting influence on moleucular species of triacylglycerols in sunflower seeds (Helianthus annuus L.) Food Res. Int. 34: 613- 619.

7. Yoshida, H., I. Kondo, and G. Kojimoto (1992) Effects on microwave energy on the relative stability of vitamin $E$ in animal fats, J. Sci. Food Agric. 58: 531-534.

8. Lee, Y. C., I.H. Kim, J. Change, Y.K. Rhee, H.I. Oh, and H.K. Park (2004) Chemical composition and oxidative stability of safflower oil prepared with expeller from safflower seeds roasted at different tempratures, J. Food Sci. 69: 33-38.

9. Albie, T., A. Lanzon, A.Guinda, M. Leon, and M. C. Perezcamino (1997) Microwave and conventional heating effects on the thermoxidative degradation of edible fats, J. Agric. Food Chem. 45: 3795-3798.

10. Yoshida, H., and G. Komjimoto (1994) Microwave heating effects composition and oxidative stability of sesame (sesamum indcum) oil, J. Food Sci. 58: 616-625.

11. Giese. J. H (1987) Special report: Advances in microwave food processing, J, Food Technol. 41: 92-99. 
12. Lubec, G., C. Wolf and S. Bntosch (1985) Amino acid isomerization and microwave exposure Lancet ii: 1392-1393.

13. Yoshida, H., and Takagi (1999) Microwave roasting and molecular species of triacylglycerols in soybean embryonic axes, J. Am. Oil Chem. Soc. 76:10651071.

14. A.O.C.S. (1996) The Official and Tentative Methods of the American Oil Chemist's Society, 3rd Ed. American Oil Chemist's Society, 508 South Sixth Street, Champaign, Illinois.

15. International Union of Pure and Applied Chemistry (IUPAC) (1987) Standard Methods for the Analysis of Oils and Fats and Derivativs, 7th revised and enlarged edn., edited by $C$. Raquot and $A$. Hautfenne, Blackwell Scientific, London.

16. Mitruk, B.N. (1984) Gas Chromatographic Applications in Microbiology and Medicine, John Wiley and Sons, Inc., New York.

17. Pons, W. A., J. C. Cuck and V. L. Frampton (1960) Colour index for cotton seed oils, J. Am. Oil Chem. Soc. 37: 671-673.

18. SAS (2004) Statistical Analysis System. SAS User's Statistical SAS Institute Inc. Editors, Cary, NC.

19. Young, C.T (1996) Linseed oil, in: Bailey's Industrial Oil and Fat Products, 5th Ed., Edited by Y. H. Hui. John Wiley\&sons. New York.
20. Farag, R. S., F. M. Hewedi. S. H. Abu-Raiia and G. S. El-Baroty (1992) Comparative study on the deterioration of oils by microwave and conventional heating, J. Food Port. 55:722-727.

21. Yoshida, H., N. Hirooka and G. Kajimoto (1990) Microwave energy effects on quality of some seed oils, J. Food Sci. 55: 1412-1416.

22. Hassanein, M. M, O. M. El-Kinawy and A. G. AbdelRazek (2010) Effects of natural $\alpha$ - tocopherol, $\beta$ carotene and their mixtures on accelerated oxidative stability of stripped sunflower oil, J.Agric. Chem. Biotech. Mansoura Univ. Egypt 1: 105-1221.

23. Kim, J. H.; Hahm, S. T. and Min, B. D (2007) Hydroperoxide as a perooxidant in the oxidative stability of soybean oil, J. Am. Oil Chem. Soc. 84: 349-355.

24. Warner, K. and Frankel, E. N (1987) Effects of $\beta$ carotene on light stability of soybean oil, J. Am. Oil Chem. Soc. 64: 213-218.

25. Yoshida, H., and S. Takagi (1996) Vitamin E and oxidative stability of soybean oil prepared with beans at various moisture contents roasted in a microwave oven, J. Sci. Food Agric. 72: 111-119.

26. Hassanein, M.M., S.M. El-Shami, and M. H. Al-Mallah (2003) Changes occurring in vegetables oils composition due to microwave heating, Grasas Aceites 54: 343-349. 